\title{
ARTROCENTESE EM ARTICULAÇÃO TEMPOROMANDIBULAR - RELATO DE CASO
}

Wanderley da Silva FÉLIX JUNIOR, Rafael Vilson SILVA, Rafaela SCARIOT, Delson COSTA

A artrocentese é um procedimento cirúrgico minimamente invasivo indicada em casos de desarranjos internos da articulação temporomandibular (ATM), deslocamento anterior de disco (com ou sem redução) e limitação de abertura bucal de ordem articular. Este trabalho relata o caso clínico da paciente G.R.H., gênero feminino, 70 anos de idade que procurou o Serviço de Cirurgia e Traumatologia Buco-maxilo-faciais do Hospital XV (Curitiba-PR). Ao exame clínico a paciente referiu dor na região da ATM e observou-se limitação severa de abertura bucal. Ao exame de imagens observou-se deslocamento anterior de disco (uni ou bilateral). O tratamento proposto foi a artrocentese da ATM, seguida pela infiltração de ácido hialurônico, sob anestesia geral. A paciente também foi submetida a 10 sessões de fisioterapia de ATM. A artrocentese junto a infiltração de ácido hialurônico mostrou-se eficaz em restabelecer a abertura bucal e diminuir o quadro álgico, em função da diminuição dos mediadores de dor local.

Palavras-chave: Artrocentese; Cirurgia; ATM 